\title{
ATRIBUSI KEKERASAN DALAM RUMAH TANGGA DAN STRATEGI COPING ISTRI KORBAN KEKERASAN DALAM RUMAH TANGGA DI KABUPATEN PONOROGO
}

\author{
Ridho Rokhamah
}

\begin{abstract}
Abstrak:
Penyelesaian masalah setiap perempuan korban kekerasan dalam rumah tangga (KDRT) sangat tergantung dari atribusi kekerasan perempuan. Usaha untuk menghadapi tekanan dan kondisi yang menyakitkan atau mengancam dikenal dengan istilah strategi coping. Penelitian ini bertujuan untuk mengungkap bagaimana atribusi dan strategi coping korban KDRT, serta bagaimana faktor-faktor yang mempengaruhi strategi coping korban KDRT di Kabupaten Ponorogo. Pendekatan penelitian yang digunakan dalam penelitian ini adalah pendekatan kualitatif. Kesimpulan penelitian ini adalah (1) Atribusi kekerasan isteri korban KDRT dibedakan menjadi faktor internal dan faktor eksternal. Adapun dimensi atribusi kekerasan isteri adalah lokasi penyebab terjadinya kekerasan, stabilitas danaya kekerasan, dan pengendalian diri terhadap kekerasan. (2) Strategi coping yang dipergunakan isteri dalam menghadapi kekerasan suami bisa dibedakan menjadi dua yaitu Problem Focused coping (PFC) dan Emotional Focused Coping (EFC). (3) Strategi PFC dipilih ini karena dipengaruhi oleh: faktor internal individu yaitu karakteristik pada kelima individu informan yang cenderung bersabar dan bertahan ketika mendapatkan tekanan, serta faktor eksternal individu yaitukemampuan dan pengalaman yang dilakukan, dan kemampuan secara finansial. Adapun strategi EFC dipilih karena adanya faktorinternal dari diri yang mempunyai karakter sabar, pasrah, dan menyerah sebelum permasalahan terjadi lebih lanjut, serta faktor eksternal yaitu keluarga yang memang terkesan pasif atas permasalahan yang dihadapi oleh korban.
\end{abstract}

Kata kunci:Atribusi, Strategi Coping, dan kekerasan. 


\section{PENDAHULUAN}

Kekerasan terhadap perempuan sebenarnya bukan masalah yang baru untuk di bahas, tetapi karena masalah ini tetap menjadi trending topic dalam berbagai media elektronik, koran, dan selalu menduduki jumlah yang tidak sedikit dalam laporan UPPA Polres serta PPT/ WCC maupun lembaga perlindungan perempuan khususnya di Kabupaten Ponorogo, maka mengkaji masalah kekerasan perempuan tetap menarik untuk dilakukan.

Menurut data Komite Perlindungan Perempuan dan Anak (KPPA) Kab. Ponorogo mulai tahun 2013 sampai dengan 2016, korban kekerasan dalam rumah tangga di dominasi oleh istri. Pada tahun 2013 jumlah kasus kekerasan dalam rumah tangga yang dilaporkan oleh istri ada 11 kasus, tahun 2014 ada 8 kasus, tahun 2015 ada 9 kasus, dan tahun 2016 ada 11 kasus. Berdasarkan data KPPA tersebut, bentuk kekerasan yang terjadi terhadap istri tersebut adalah kekerasan psikis, kekerasan fisik, dan penelantaran. Kekerasan psikis tersebut ada yang berbentuk verbal dan ada yang berupa sikap, misalnya perselingkungan, kekerasan fisik dalam bentuk pemukulan, dan kekerasan penelantaran seperti penghentian pemberian nafkah ${ }^{1}$.

Dari sejumlah kasus yang dilaporkan kepada Komite Perlindungan Perempuan dan Anak (KPPA) di atas, beberapa di antarannya akhirnya sampai berlanjut di Polres maupun Pengadilan (seperti perceraian). Dalam wawancara awal yang peneliti lakukan terhadap korban DY ketika ditanyakan apa masalah yang terjadi dalam rumah tangganya, dia menjawab;

"sejak awalpernikahan saya sudah sering mendapatkan perlakuan yang tidak nyaman dari suami, saya sampai keluar kerja karena suami menghendaki saya di rumah. Tetapi setelah saya keluar kerja suami tidak memberikan saya nafkah yang cukup, sehingga saya bingung harus mencari tambahan. Setiap hari saya diberi jatah 20 ribu rupiah untuk belanja. Padahal sekarang semua serba mahal, bagaimana saya bisa bertahan untuk hidup. Suami juga sering uring-uringan kalau ada yang tidak cocok, sehingga saya harus menjaga perasaan ibu saya yang tinggal bersama saya dan juga anakanak. Untuk kebutuhan anak-anak sekolah saya tidak diberi kepercayaan untuk membayarkannya, akhirnya saya minta kepada wali kelasnya untuk memanggil suami saya jika waktu pembayaran sekolah. Saya juga heran

${ }^{1}$ Data dari hasil kesimpulan terhadap dokumen laporan kasus KPPA Kab. Ponorogo tahun 2013 s.d. 2017. 
padahal suami saya gajinya lumayan banyak ada sekitar 4 juta rupiah setiap bulannya, tapi entah mengapa kepada keluarganya dia berbuat seperti itu. Tapi saya masih tetap harus bertahan demi anak-anak saya".

Kasus kekerasan yang menimpa pada ibu DY di atas sebenarnya sudah cukup berat, tetapi demi mempertahankan anak-anaknya dia tetap bertahan dalam pernikahannya. Lebih dari 10 tahun DY telah bertahan dan menerima semua bentuk kekerasan yang dilakukan suaminya, mulai kekerasan psikis, fisik, penelantaran dalam rumah tangga, dan pembatasan ruang geraknya. Sebelum menikah DY sebenarnya sudah bekerja tetapi karena suaminya menghendaki dia untuk berhenti akhirnya DY mematuhinya. Namun seiring waktu ternyata suami DY memperlakukan DY dengan sangat kejam dengan tidak memberikan nafkah lahir dan juga membatasi semua aktifitas DY.

Kisah yang hampir sama juga disampaikan oleh korban yang berinisial SS. SS mengalami kekerasan dalam rumah tangga sejak awal pernikahan, di mana suaminya tidak pernah memberikan nafkah lahir yang memadai dan membatasi ruang gerak SS untuk bekerja. Namun karena pertimbangan anak-anak akhirnya SS tetap mempertahankan pernikahannya. Dalam pengaduannya SS mengatakan;

"Sejak awal pernikahan suami saya memang kasar dan pelit. Saya tidak pernah diberikan uang tunai untuk belanja lebih dari 50 ribu rupiah. Selama ini beras sudah disediakan, tapi untuk urusan lain-lain suami tidak mau tahu. Bila waktunya mengerjakan sawah, saya diberi uang untuk belanja tapi jumlahnya selalu kurang. Untuk memenuhi kebutuhan hidup, dulu saya mengajar tapi oleh suami di suruh keluar, setelah saya keluar kerja saya tidak diberi jatah untuk belanja. Belanja disiapkan tapi sangat tidak cukup untuk kami makan. Akhirnya saya bekerja lagi menjadi PRT. Mengetahui saya bekerja lagi, dia malah semakin pelit kepada saya dan anak-anak. Padahal uang yang saya dapatkan dari hasil bekerja saya pergunakan untuk biaya anak-anak sekolah. Terkadang saya menahan sakit dan benci kepada suami saya. Tapi bagaimana lagi, kasihan anak-anak kalau saya pisah. Saya sudah bekerja 15 tahun dan anak-anak sudah pada bekerja tetapi kelakuan suami saya tetap tak berubah. Apalagi sekarang saya sakit dan tidak kuat untuk bekerja, suami saya pelit. Tapi karena desakan dari anakanak saya akhirnya suami mau memberikan nafkah 50 ribu rupiah setiap

${ }^{2}$ DY, Wawancara 12 April 2017.

Kodifikasia, Volume 11 No. 1 Tahun 2017 
minggunya. Uang segitu apa ya cukup. Mau bagaimana lagi saya harus tetap bertahan, karena saya kasihan dengan anak-anak kalau bercerai"'.

Jika dicermati 2 kasus kekerasan dalam rumah tangga yang terjadi pada DY dan SS tersebut, maka bisa diambil kesimpulan bahwa kedua wanita tersebut mengalami kekerasan, 1) psikis, karena menghadapi tekanan secara terus menerus dari pasanganya, 2) dibatasi ruang geraknya, dan 2) penelantaran, karena tidak diberikan nafkah yang cukup oleh suaminya. Namun pertanyaan yang mendasar selalu muncul dalam benak peneliti dan juga relawan yang mendampingi korban, mengapa mereka tetap bertahan?, dan bagaimana cara mereka tetap bertahan?.

Berbeda dengan 2 kasus di atas, korban atas nama TT akhirnya mengambil langkah ke jalur hukum ketika kasus kekerasan terus menimpanya, dalam wawancara dia menyampaikan;

"Saya sampai bingung dengan perubahan sikap suami saya. Jika biasanya dia masih mau menyapa dan berkomunikasi dengan baik sekarang ini kok ada perubahan yang sangat drastis. Setelah saya telusuri ternyata dia sudah berselingkuh, dan saya mendapatkan informasi kalau dia sudah membeli rumah dengan selingkuhannya. Ketika saya tanya dia mengakuinya. Padahal anak-anak saya sudah kuliah. Akhirnya, setelah berdiskusi dengan anak-anak saya putuskan bercerai dari pada saya menahan sakit terus menerus"'.

Sikap yang dipilih oleh TT tersebut menunjukkan adanya keberanian yang muncul dari hati TT untuk memilih menyelesikan permasalahan dalam rumah tangganya dengan menempuh jalur pengadilan. Penyelesaian masalah yang dipilih oleh TT karena terdapat point penting yang tidak bisa diberikan kata maaf oleh banyak perempuan yaitu pengkhiatan dalam perkawinan. Dalam banyak kasus yang dilaporkan, perempuan akan tetap bertahan dengan kondisi apapun ketika suami melakukan kekerasan, tapi mereka tidak akan bisa menerima jika sudah menyangkut masalah perselingkuhan.

Keputusan berpisah yang diamil oleh TT tidak banyak dipilih oleh istri. Kasus yang hampir serupa dengan TT juga terjadi kepada AN, tetapi AN tetap ingin mempertahankan rumah tangganya

${ }^{3}$ SS, Wawancara, 02 April 2017.

${ }^{4}$ TT, Wawancara, 16 maret 2016. 
meskipun dia dalam kondisi tertekan karena adanya perselingkuhan, dalam pengaduannya AN mengatakan;

"Ada perubahan sikap pada suami saya. Sekarang dia suka pergi pada jam tertentu yang menurut saya aneh. Kalau sudah pegang HP bisa berjam-jam dia menyendiri. Kemana-mana HP itu selalu di bawa, dan dia sembunyikan. Terkadang dia itu gelisah dan telpon malam-malam. Saya pura-pura tidur untuk mendengarkan komunikasinya. Saya harus bertindak bagaiamana karena keluarga suami seperti tidak perduli. Sampai akhirnya saya sangat marah kepada dia, meskipun awalnya tidak mengakui tapi akhirnya dia mengakui juga. Dia bilang tetap akan jadi suami saya meskipun hatinya sudah terbagi. Saya sangat sakit mendengarnya, tapi bagaimana lagi, saya pasrah, saya harus tetap bertahan demi anak-anak saya"

Berdasarkan pernyataan AN ini bisa disimpulkan bahwa ada nada kekecewaan dan ketidakmampuan dia dalam menghadapi permasalahan yang dihadapinya. Mempertahankan diri dalam kondisi yang tertekan secara terus menerus sebenarnya bisa mempunyai dampak yang kurang baik bagi kehidupan AN. Karena kekerasan terhadap perempuan merupakan masalah yang serius dalam bidang kesehatan dan bisa melemahkan energi perempuan, mengikis kesehatan fisik dan harga dirinya. Disamping itu juga dapat memperbesar resiko jangka panjang terhadap masalah kesehatan lainnya, termasuk penyakit kronis dan depresi. ${ }^{6}$

Berdasarkan fakta wawancara kepada istri korban kekerasan dalam rumah tangga di atas, maka bisa disimpulkan bahwa sikap istri dalam menghadapi masalah kekerasan sangat beragam, namun dalam beberapa kasus terdapat satu kesamaan yaitu bertahan. Ini menarik untuk diteliti lebih mendalam, mengapa banyak istri yang memilih bertahan dalam menghadapi masalah kekerasan yang dihadapinya.

Penyelesaian masalah setiap perempuan korban kekerasan dalam rumah tangga sangat tergantung dari atribusi ${ }^{7}$ kekerasan perempuan tersebut. Perempuan korban KDRT yang memiliki atribusi kekerasan eksternal, dapat dikendalikan, serta tidak stabil,

${ }^{5} \mathrm{AN}$, Wawancara, 14 April 2017.

${ }^{6}$ Muhammad Hakimi dkk (Ed), Membisu Demi Harmoni "Kekerasan Terhadap Istri dan Kesehatan Perempuan di Jawa Tengah, Indonesia”, (LPKGM-FK-UGM Yogyakarta, Rifka Annisa WCC Yogyakarta, Umea University Sweden, Women's Health Exchange USA: 2001), cet. 1 , h. 1.

${ }^{7}$ Suatu penilaian yang hampir setiap waktu digunakan oleh individu adalah penilaian sebab akibat yang disebut dengan atribusi. 
cenderung menggunakan problem focused coping dalam menghadapi kekerasan dari suaminya ${ }^{8}$.

Apabila istri korban kekerasan memandang bahwa kekerasan yang terjadi pada dirinya merupakan penyebab dari luar dirinya, ia akan merasa dirinya menjadi korban, oleh karena itu dia akan melakukan sesuatu untuk memecahkan problem yang menimpa dirinya tersebut secara langsung pada sumber masalah. Dengan cara itu dia berharap bisa keluar dari masalah yang dihadapinya ${ }^{9}$. Begitu juga sebaliknya, jika istri cenderung rendah dan menyalahkan diri sendiri, dia akan semakin kesulitan untuk menghentikan kekerasan tersebut.

Usaha untuk mengahadapi tekanan dan kondisi yang menyakitkan atau mengancam tersebut dikenal dengan istilah strategi coping. Strategi coping merupakan kecenderungan bentuk tingkah laku individu untuk melindungi dirinya dari tekanantekanan psikologis yang ditimbulkan dari problematika sosial ${ }^{10}$.

Berangkat dari fakta kekerasan terhadap istri dan atribusi kekerasan dalam rumah tangga yang beragam, maka peneliti tertarik mengkaji lebih mendalam bagaimana atribusi kekerasan dalam rumah tangga serta bagaimana strategi penyelesaian masalah istri korban kekerasan dalam rumah tangga tersebut. Serta faktor apa saja yang melatarbelakangi pengambilan keputusan atau strategi coping yang dilakukan oleh isteri korban kekerasan dalam rumah tangga. Pertanyaan-pertanyaan tersebut menarik untuk ditindaklanjuti dalam penelitian.

\section{PEMBAHASAN}

\section{Atribusi Kekerasan Istri Korban Kekerasan dalam Rumah Tangga di Kabupaten Ponorogo}

Atribusi merupakan suatu proses penilaian tentang penyebab yang dilakukan individu setiap hari terhadap berbagai peristiwa, dengan atau tanpa disadari ${ }^{11}$. Pengertian atribusi adalah mencari penjelasan-

${ }^{8}$ Siti Rohmah Nurhayati. "Peningkatan Kemampuan Menggunakan Problem Focused Coping Perempuan Korban Kekerasan dalam Rumah Tangga”. Humanita: Indonesia Psicological Journal Vol. 3 No. 1 Januari 2006). 23-24.

${ }^{9}$ Ibid.

${ }^{10} \mathrm{Ibid}$.

${ }^{11}$ Nurhayati, Peningkatan.....Ibid. 23. 
penjelasan sebab akibat atas berbagai peristiwa sosial, terutama terhadap tindakan yang dilakukan oleh seseorang. Teori atribusi adalah teori bagaimana orang menjelaskan perilaku orang lain. Menurut Weiner ${ }^{12}$ Atribusi terdiri dari 3 dimensi yaitu;

1. Lokasi penyebab. Masalah pokok yang paling umum dalam persepsi sebab akibat adalah apakah suatu peristiwa atau tindakan tertentu disebabkan oleh keadaan internal (hal ini disebut sebagai atribusi internal) atau kekuatan eksternal (atribusi eksternal);

2. Stabilitas. Dimensi sebab akibat yang kedua adalah berkaitan dengan pertanyaan apakah penyebab dari suatu peristiwa atau perilaku tertentu itu stabil atau tidak stabil. Dengan kata lain, stabilitas mengandung makna seberapa permanen atau berubahubahnya suatu sebab;

3. Pengendalian. Dimensi ini berkaitan dengan pertanyaan apakah suatu penyebab dapat dikendalikan atau tidak dapat dikendalikan oleh seorang individu. Teori atribusi menyatakan bahwa setelah mengalami peristiwa yang negatif atau menyakitkan, orangorang membuat atribusi untuk memudahkan penyesuaian, karena atribusi membantu mereka merasa bahwa mereka dapat mengontrol lingkungan dan reaksi mereka sendiri.

Berdasarkan teori di atas, maka beberapan fakta terkait atribusi informan bias dilihat berdasarkan hasil wawancara berikut, pendapat KYM terkait penyebab suaminya akhirnya melakukan kekerasan psikis adalah 1 . Karena masalah ekonomi yang akhirnya menyebabkan dia pergi ke luar negeri dan suaminya di rumah tidak mendapatkan perhatian, 2. Suaminya tidak mau bekerja dan mengandalkan kiriman gaji dari KYM, sedangkan uang tersebut selain untuk memenuhi kebutuhannya sehari-hari juga dipergunakan untuk berfoya-foya, 3. Ketidakhadiran anak selalu menjadi pemicu bagi keduanya untuk bertengkar dan berbeda pendapat. Meskipun permasalah yang menyebabkan kekerasan adalah kompleks, namun KYM menyadari bahwa ketidakhadiran anak selalu menjadi bahan perbedaan pendapat di antara keduanya. Jika dilihat dari informasi

${ }^{12}$ Weiner dalam Nurhayati...Ibid. Lihat juga dalam Jay A. Mclean, Kenneth T. Strongman, Psycological Distress, Causal Attributions, and Coping, New Zealand Journal Of Psicology, Vol. 36, No. 2, July 2007, 85. 
yang KYM berikan, maka penyebab kekerasan berasal faktor internal dirinya yang tidak bisa memberikan keturunan. Dan kemudian faktor-faktor lain atau faktor eksternal semakin memperburuk konflik keduanya.

Permasalahan kekerasan yang lain adalah kekerasan yang menimpa BT. Pada permasalahan ini terdapat karakteristik yang sama dengan KYM yaitu kekerasan psikis akibat masalah ekonomi, namun ada hal khusus yang membedakan antara KYM dan BT yaitu 1. Suami KYM tidak mau bekerja dan suka berfoya-foya, sedangkan suami BT masih mau bekerja meskipun hasilnya masih kurang untuk memenuhi kebutuhan hidup sehari-hari, dan 2. KYM belum bisa memberikan keturunan sehingga sepertinya penyebab ketidakhadiran anak adalah salah KYM bukan karena kesalahan bersama, dan bagi BT anak justru menjadi persoalan serius ketika hendak memenuhi kebutuhan ketiga anak-anaknya karena suaminya hanya bekerja sebagai tukang becak yang penghasilannya tidak mencukupi untuk memenuhi kebutuhan tersebut.

Kesimpulan dari kekerasan yang terjadi pada BT terkait penyebab terjadinya kekerasan adalah dikarenakan faktor eksternal yaitu masalah ekonomi. Dalam masalah ekonomi ini, problem yang muncul adalah ketika suami BT yang berprofesi sebagai tukang becak dengan penghasilan tidak menentu dan tidak dapat memenuhi kebutuhan hidup keluarganya, maka dia akhirnya melakukan kekerasan terhadap isterinya dengan cara menyuruh isterinya terus mencari pinjaman untuk memenuhi kebutuhan hidupnya.

Selanjutnya adalah pengalaman yang dirasakan oleh SP dan YT di mana keduanya mempunyai problem kekerasan yang hampir sama, yaitu: 1. Sama-sama hidup dengan mertua, dan sering disalahkan jika terjadi konflik dengan suaminya, 2. Sama-sama dalam kondisi ekonomi yang kurang, 3. Sama-sama mengambil jalan keluar menjadi TKW untuk memenuhi kebutuhan hidupnya, dan 4. Sama-sama menjadi korban kekerasan psikis karena suaminya berfoya-foya dan menghabiskan uang hasil kerjanya di luar negeri serta berselingkuh.

Kasus yang sama juga dialami oleh JA ketika dia harus menjadi TKW ke luar negeri. Nasib JA sama dengan SP dan YT, di mana selama dia di Luar negeri suaminya berselingkuh dan menghabiskan semua uang yang telah dia kirimkan kepada suaminya. 
Ketiga informan yaitu SP, YT, dan JA, mempunyai pandangan yang sama bahwa penyebab terjadinya kekerasan karena adanya faktor dari luar dirinya yaitu masalah ekonomi yang memicu mereka pergi ke luar negeri, suaminya berselingkuh dan menghabiskan uang yang telah dikirimkan.

Berangkat dari hasil wawancara di atas, maka bisa disimpulkan bahwa pandangan isteri terhadap penyebab terjadinya kekerasan ada 2 klasifikasi:

1. Faktor internal: istri menganggap penyebab terjadinya kekerasan karena dirinya yang tidak bisa memberikan keturunan, merasa tidak cantik lagi, dan lemah.

2. Faktor eksternal: a. masalah ekonomi, b. suami memang mempunyai karakter yang keras, tidak mau bekerja, berfoya-foya, dan berselingkuh. c. karena pihak ketiga yang memprovokasi yaitu keluarga atau orang tua.

Sedangkan dimensi atribusi kekerasan isteri berdasarkan hasil wawancara di atas jika dianalisis dengan pendapat Weiner, maka:

1. Lokasi penyebab. Berdasarkan hasil wawancara, lokasi penyebab terjadinya kekerasan ada sebagian yang berpendapat itu berasal dari internal (istri) dan ada yang berpendapat berasal dari faktor eksternal (suami, keluarga, dan ekonomi).

2. Stabilitas. Berdasarkan hasil wawancara dapat dianalisis bahwa beberapa kekerasan terjadi secara terus menerus dan stabil, namun ada sedikit yang mengakui bahwa kekerasan terkadang stabil tapi dalam satu waktu tidak stabil.

3. Pengendalian. berdasarkan hasil wawancara, para istri korban kekerasan dalam rumah tangga rata-rata bisa mengendalikan diri atas tindakan yang dilakukan suami. Istri yang memandang penyebab kekerasan adalah karena dirinya, lebih cenderung sabar dan bertahan atas semua tindakan suaminya, bahkan menerima semua perlakuan suaminya meskipun harta yangdihasilkan atas jerih payahnya telah dihabiskan. Sedangkan istri yang menganggap bahwa kekerasan muncul karena sebab faktor di luar dirinya, juga berusaha mengendalikan dirinya, hanya saja pada titik dimana suami telah mengkhianatinya, dia berusaha melepaskan ikatan di antara mereka dengan perceraian. 
Kesimpulan yang bisa diambil adalah, isteri yang memandang kekerasan berasal dari internal dirinya cenderung sabar, diam, emosional, dan menerima kekerasan yang terjadi pada dirinya, sedangkan individu yang memandang bahwa kekerasan terjadi karena faktor eksternal cenderung aktif melakukan upaya keluar dari kekerasan dan terus mencari solusi terbaik agar bisa keluar dari kekerasan yang menimpanya, meskipun solusi akhirnya (setelah semua usaha yang dia lakukan tidak membuahkan hasil) adalah perceraian. Fakta ini sesuai dengan pendapat Follette dan Jacobson yang menyatakan orang yang mengatribusikan peristiwa yang dialaminya pada sesuatu yang di luar dirinya akan memiliki cara yang berbeda untuk menghadapi peristiwa tersebut dibandingkan dengan orang yang tipe atribusinya internal.

\section{Strategi Coping Istri Korban Kekerasan Dalam Rumah Tangga}

Kondisi korban kekerasan dalam rumah tangga yang mendapat tekanan terus menerus bisa memicu stres. Dalam menghadapi masalah stres ini secara otomatis masing-masing individu akan melakukan perlawanan. Namun perlawanan pada masing-masing individu tentunya berbeda. Menurut Taylor, coping adalah kecenderungan umum yang digunakan individu untuk menangani peristiwa stres dengan cara-cara tertentu. Sedangkan Pearlin dan Scholeer berpendapat bahwa strategi coping merupakan kecenderungan bentuk tingkah laku individu untuk melindungi diri dari tekanantekanan psikologis yang ditimbulkan oleh problematikan sosial ${ }^{13}$.

Lazarus menambahkan, strategi coping merupakan usaha secara kognitif dan perilaku untuk mengurangi, mengatasi, atau melakukan toleransi terhadap tuntutan internal dan eksternal yang terjadi karena adanya transaksi dengan lingkungan yang penuh stress. Sehingga bisa disimpulkan strategi coping bisa berupa pikiran, perasaan, sikap, maupun perilaku individu dalam usahanya untuk mengatasi, menahan atau menurunkan efek negatif dari situasi yang bersifat mengancam ${ }^{14}$.

Dalam membangun perilaku coping diperlukan sumberdaya coping baik yang bersifat fisik maupun non fisik. Sumberdaya coping cenderung bersifat subyektif sehingga perilaku coping dapat bervariasi

${ }^{13}$ Pearlin dan Scholar dalam Nurhayati, Peningkatan ..., 20.

${ }^{14}$ Ibid. 
pada setiap orang. Dukungan sosial merupakan sumber daya coping yang mempunyai pengaruh sangat penting dalam strategi coping. Dukungan sosial diperoleh dari orang tua, saudara atau anggota keluarga lainnya, teman, dan lingkungan masyarakat sekitar. Dengan adanya dukungan sosial, maka individu akan semakin mampu dan yakin dalam memecahkan masalah yang dihadapi serta dapat membantu individu dalam memilih strategi coping yang tepat.

Berdasarkan hasil wawancara, maka bisa disimpulkan bahwa strategi coping istri korban kekerasan dalam rumah tangga di Kabupaten Ponorogo adalah:

1. Ada yang penyelesaian kasusnya dengan cara mencari solusi kepada keluarga, dilanjutkan ke RT, dan kelurahan, dan akhirnya sampai kepada lembaga yang berwenang.

2. Meminta nasehat kepada keluarga, dan ketika sudah tidak berhasil mereka membiarkan kasus kekerasan terjadi dan pasrah terhadap nasib yang menimpanya.

3. Mengambil tindakan membicarakan masalah kepada keluarga, meminta pihak-pihak terkait untuk memediasi, dan ketika tetap tidak berhasil akhirnya mengajukan gugatan perceraian.

4. Mengambil tindakan yang cukup arogan yaitu langsung mengajukan perceraian tanpa menunggu waktu mediasi atau membicarakan dengan keluarga terlebih dahulu.

Sedangkan strategi yang dipergunakan bisa disimpulkan menjadi dua yaitu dengan Problem Focused coping dan emotional focused coping. Pembagian tersebut jika dilihat dengan teori sosial, maka hasil analisisnya adalah:

1. Korban yang menggunakan Problem Focused Coping (PFC) sebagaimana pendapat Lazarus dan Folkmanterkait perilaku coping, maka untuk kasus yang terjadi di Kabupaten Ponorogo, perilaku coping tersebut adalah:

a. Korban menggunakan Planfull problem solving, di mana korban sebelum bertindak dia telah mempertimbangkan alternatif pemecahannya. Mereka meminta pendapat dan pandangan dari orang lain tentang masalah yang dihadapi, bersikap hati-hati sebelum memutuskan sesuatu dan mengevaluasi strategi yang pernah dilakukan. Informan yang masuk dalam kategori ini adalah BT, YT, SP, dan JA. 
b. Seeking social support, suatu cara yang dilakukan individu dalam menghadapi masalah dengan mencari dukungan pada keluarga atau lingkungan sekitar, dapat berupa informasi, bantuan nyata, simpati, maupun perhatian.Para informan korban kekerasan ini dalam melakukan strategi coping dia sudah melakukan tahapan meminta pendapat dengan keluarga, ketua RT, Kelurahan, dan lembaga yang berwenang. Mereka melakukan tindakan secara hati-hati dengan meminta pendapat pada orang yang dianggap bisa membantu menyelesaikan sosulinya.

Selanjutnya Jika dianalisis dengan menggunakan Problem Focused copingsebagaimana teori Carver, maka:

a. Active coping atau menghadapi masalah secara aktif, beberapa informan melakukan reaksi atas kekerasan yang menimpanya dengan melakukan komunikasi kepada suami dan ketika tidak berhasil dia meminta bantuan keluarga selanjutnya RT, kelurahan dan lembaga yang berwenang.

b. Planning atau perencanaan, secara berhati-hati beberapa informan mencari solusi dengan melalui beberapa tahapan sampai akhirnya dia memutuskan untuk melakukan perceraian,

c. Using instrumental support, individu mencari dukungan sosial karena alasan instrumental, antara lain dengan mencari nasehat, maupun informasi guna menyelesaikan permasalahan yang dihadapi.

2. Korban yang memilih Emosional Focused Coping, korban yang melakukan strategi dengan EFC hanya 2 orang yaitu KYM dan RY. KYM adalah seorang istri yang mendapatkan kekerasan psikis dan penelantaran dalam rumah tangga yang disebabkan ketidakhadiran anak dan ekonomi, namun KYM menyadari semua berawal dari ketidakhadiran anak setelah menikah 20 tahun. Sedangkan RY adalah seorang isteri yang menjadi korban kekerasan psikis dan penelantaran dalam rumah tangga. Meskipun dia menyadari penyebab terjadinya kekerasan adalah orang lain, namun dia satu-satunya korban yang memilih menyelesaikan kasus kekerasan yang menimpanya dengan EFC. 
Berdasarkan hasil wawancara terhadap KYM dan RY dapat dianalisis dengan teori Carver dimana EFC ini mempunya 8 strategi yaitu;

a. Mencari dukungan karena alasan emosional, yaitu KYM dan RY berusaha mencari dukungan terhadap keluarganya (ayah, ibu, dan keluarga dekat). Namun jika dicermati hasil wawancara dengan RY, dia lebih bersifat pasif atas masalah yang menimpanya. Dalam menghadapi masalah dia hanya meminta dukungan dari orang tuanya.

b. Pelepasan emosi, yaitu kecenderungan untuk memusatkan pada gangguan apapun dan melepaskan emosi yang dirasakannya, untuk menghilangkan tekanan yang telah KYM dan RY rasakan, keduanya tetap beraktifitas sepertia biasa, dimana KYM bekerja di luar negeri dan RY tetap menjadi guru les,

c. Tindakan pelarian, yaitu bekerja merupakan tindakan pelarian atas semua tekanan masalah, KYM pergi ke luar negeri untuk menghilangkan tekanan psikisnya dan RY karena sejak awal hidup dengan orang tuanya, maka dia tetap tinggal di rumah orang tuanya, sedangkan suaminya pulang ke rumah orang tuanya sendiri.

d. Pelarian secara mental, untuk menghilangkan beban mental yang dihadapi KYM pergidengan melakukan aktifitas yang jauh dari suaminya, seperti bekerja ke luar negeri,

e. Reinterpretasi dan perkembangan yang positif, yaitu mengatur emosi yang berkaitan dengan distress, bukannya menghadapi stressor itu sendiri. RY tidak bisa menghadapi suaminya yang telah meninggalkan dia dan anak yang ada dalam kandungannya, dia tidak berusaha menghadapi suaminya dan membiarkan suaminya pergi sampai akhirnya menceraikan dia.

f. Penolakan, yaitu menolak untuk percaya bahwa sterssor itu ada atau mencoba bertindak bahwa stressor itu tidak nyata, KYM dan RY tetap berharap suami berubah dan tidak menganggap bahwa kekerasan telah terjadi kepadanya dia hanya pasrah,

g. Penerimaan, yaitu individu menerima kenyataan akan situasi yang penuh stress, menerima kenyataan tersebut pasti terjadi, beberapa informan menyadari bahwa kekerasan itu terjadi dan dia memahami atas tindakan yang sudah dilakukan oleh 
suaminya, dalam hal ini, RY akhirnya mencari dukungan dari lembaga yang berwenang setelah 3 tahun perceraiannya dan suaminya tidak memberikan nafkah anaknya. Tindakan ini bisa dikatakan terlalu lama setelah pasrah selama 3 tahun dengan tidak melakukan tindakan apapun untuk mempertahankan rumah tangganya.

\section{Faktor-Faktor yang Mempengaruhi Strategi Coping Istri Korban Kekerasan Dalam Rumah Tangga}

Berdasarkan hasil wawancara dengan informan, terdapat 2 klasifikasi model strategi yang dipergunakan dalam menyelesaikan masalah yang telah menimpa dia, yaitu; sebagian informan menggunakan Problem Focus Coping (PFC) dalam menyelesaikan masalah yang dihadapi dan sebagian informan menggunakan Emosional Focus Coping(EFC).

Faktor-faktor yang membuat korban memilih strategi PFC atau EFC menurut Taylor dipengaruhi oleh dua faktor yaitu faktor internal dan faktor eksternal. Faktor internal adalah faktor yang ada dalam individu, seperti karakteristik, sifat kepribadian, dan metodecoping yang digunakan. Sedangkan faktor eksternal adalah faktor yang berasal dari luar individu seperti, waktu, uang, pendidikan, kualitas hidup, dukungan keluarga, dan sosial.

Faktor yang dianggap sangat berpengaruh terhadap strategi coping adalah penilaian kognitif. Menurut Folkman dkk., pemilihan strategi yang akan digunakan oleh individu dalam mengahadapi suatu msalah dipengaruhi oleh penilaian individu terhadap masalah tersebut dan penilaiannya terhadap potensi yang dimilikinya untuk mengahadapi masalah itu. Penilaian semacam itu disebut dengan penilaian kognitif ${ }^{15}$.

Selanjutnya Folkman menjelaskan bahwa penilaian terhadap sesuatu yang dihadapinya dan penilaian terhadap potensi yang dimilikinya untuk menghadapi masalah yang ada, dapat mempengaruhi terhadap strategi yang digunakan. Hal ini karena pada dasarnya setiap individu akan selalu berusaha menyesuaikan strategi yang akan digunakan dengan situasi yang dihadapi. Jika penggunakan strategi individu tersebut mengalami kegagalan, maka individu akan melakukan evaluasi kembali terhadap situasi yang ada

${ }^{15}$ Lihat Folkman dalam Nurhayati, Peningkatan....Ibid., 22.

Kodifikasia, Volume 11 No. 1 Tahun 2017 
dan mengevaluasi strategi mana yang lebih sesuai dan lebih cepat ${ }^{16}$. Beberapa faktor yang mempengaruhi strategi koping pada individu jugadikemukakan juga oleh Smet yaitu:

1. Usia, usia dapat mempengaruhi kemampuan tubuh dalam memerangi rasa sakit. Kemampuan tubuh memerangi rasa sakit sudah ada pada masa kanak-kanak, tetapi kemampuan ini menurun pada masa tua.

2. Pendidikan, individu yang memiliki pendidikan lebih tinggi akan menilai segala sesuatu secara realistis dan koping akan lebih aktif dibanding dengan individu yang mempunyai pendidikan yang rendah.

3. Status sosial ekonomi, seseorang yang memiliki status sosial ekonomi rendah bisa berdampak pada stress yang tinggi khususnya dalam masalah ekonomi, jika dibandingkan dengan seseorang yang memiliki status sosial ekonomi yang lebih tinggi.

4. Dukungan sosial, dukungan sosial yang positif dari lingkungan (keluarga, teman, dan masayarkat sekitar) sangat membantu berkurangnya kecemasan dan depresi.

5. Karakteristik kepribadian, suatu model karakteristik kepribadian yang berbeda akan mempunyai coping yang berbeda. Karakteristik kepribadian mencakup introvert-ekstrovert, stabilitas ekonomi, kepribadian ketabahan atau hardiness, locus of control, kekebalan dan ketahanan.

6. Pengalaman, pengalaman mempunyai pengaruh terhadap tindakan-tindakan individu dalam menghadapi suatu kejadian yang hampir sama.

Berangkat dari fakta terkait penyebab informan memilih strategi coping dalam menyelesaikan problem yang dia hadapi serta teori Taylor dan Smet di atas, maka dapat dianalisis bahwa faktor-faktor yang menyebabkan informan memilih strategi coping tersebut adalah; 1. Informan yang memilih strategi PFC ada 5 orang. Kelima orang yang memilih strategi PFC ini memandang bahwa penyebab terjadi kekerasan dalam rumah tangganya karena adanya faktor eksternal yaitu suami tidak bertanggung jawab, ekonomi, suami selingkuh. 
Jika diamati kondisi kelima orang informan yang memilih strategi PFC ini karena dipengaruhi oleh:

a. faktor internal individu yaitu karakteristik pada kelima individu informan yang cenderung bersabar dan bertahan ketika mendapatkan tekanan, namun setelah tekanan yang dia rasakan semakin berat, misalnya diminta terus berhutang untuk memenuhi kebutuhan hidupnya sehari selama lebih dari 3 tahun (informan BT) dan tidak diperbolehkan bertemu dengan orang tua, atau tanpa sepengetahuannya dia harus membayar hutang suaminya dan tanpa diberi nafkah sepeserpun dan itu telah berlangsung beberapa tahun (informan AS), atau kasus YT, di mana dia yang telah bekerja ke luar negeri mendapatkan kabar kalau uang yang dia kirimkan telah dihabiskan oleh suaminya, selanjutnya kasus kekerasan yang terjadi pada SP, dan JA, di mana keduanya terpaksa berangkat ke luar negeri karena untuk memenuhi kebutuhan hidupnya, namun setelah 4 tahun bekerja, uang yang dikirimkan habis untuk foya-foya suaminya dan setelah sampai di Indonesia mereka mendapati suaminya selingkuh. Semua informan tersebut akhirnya menceraikan suaminya. Semua memilih strategi PFC dalam menyelesaikan masalah yang dia hadapi, sehingga jika keputusan mereka pada akhirnya adalah perceraian, itu terjadi karena setelah dia menggunakan strategi active coping dalam menyelesaikan masalah yang dihadapi dan semua dilakukan dengan perencanaan yang matang namun akhirnya tetap tidak bisa dipertahankan. Dari kesemua informan yang memilih strategi PFC hanya YT yang bisa dikatakan dalam menyelesaikan masalah terlalu aktif dan tidak dengan perencanaan yang matang.

b. Faktor eksternal individu yaitu, yaitu dari sisi kemampuan dan pengalaman yang dilakukan, informan seperti SP, JA, dan YT, ketiganya bekerja keluar negeri dan setelah sampai di sana dia mempunyai pengalaman hidup yang lebih matang karena telah merasakan bagaimana sulitnya berjuang di negeri orang, secara finansial mereka mempunyai kemampuan untuk hidup mandiri, sehingga ketika suaminya 
telah memperlakukan mereka secara tidak adil dan berselingkuh, maka mereka berani mengambil keputusan dengan segala resiko apapun. Selain itu, dukungan keluarga juga sangat membantu mereka untuk mengambil keputusan yang tersulit dalam hidupnya. Sedangkan untuk BT dan AS, keberanian mereka muncul karena dukungan keluarga yang membantu mereka keluar dari semua persoalan yang mereka hadapi.

2. Informan yang memilih strategi EFC ini ada 2 orang. Dua orang informan yang menggunakan strategi EFC ini adalah KYM dan RY. Terdapat 2 karakteristik yang berbeda dari 2 orang tersebut yaitu:

a. Kekerasan yang dialami KYM, dia memillih bersabar, mengadu kepada keluarga, mencari simpatisan, dan akhirnya dia tetap bertahan meskipun uang hasil kerjanya selama 4 tahun sudah dihabiskan suaminya. Faktor yang menyebabkan dia memilih strategi EFC karena, pertama faktor internal, karakteristik individu KYM yang sabar dan pemaaf, dia merasa bersalah karena tidak juga mempunyai anak setelah menikah 20 tahun, disamping itu usia KYM sudah tidak muda lagi, sehingga dia sudah merasa lelah jika harus bercerai dan memulai hidup baru. Kedua faktor eksternal, meskipun secara finansial dia mampu untuk hidup mandiri, tetapi dari sisi waktu dia merasa sudah tidak muda lagi dan tidak ingin terlibat konflik lagi dengan suaminya.

b. Kekerasan yang terjadi kepada RY. Meskipun RY menyadari bahwa kekerasan yang terjadi kepadanya diakibatkan karena faktor eksternal yaitu keluarga suaminya berusaha memisahkan mereka, namun dalam mensikapi kekerasan yang terjadi kepadanya dia memilih menggunakan EFC. EFC dia pilih sebagai strategi coping karena adanya faktor, pertama faktor internal dari dirinya yang mempunyai karakter sabar, pasrah, dan menyerah sebelum permasalahan terjadi lebih lanjut. Dan kedua, faktor eksternal yaitu keluarga yang memang terkesan pasif atas permasalahan yang dihadapi oleh RY. Hal ini terbukti dengan sikap keluarga RY yang akhirnya mendukung RY melaporkan kasus penelantaran nafkah 
anak oleh suaminya setelah bercerai kurang lebih 3 tahun. Jika dilihat dari faktor kemandirian, RY juga terkesan belum bisa mandiri karena keterbatasan ekonominya, sehingga dia hanya pasrah menunggu dan berharap suaminya sadar dan kembali kepadanya.

\section{PENUTUP}

Didasarkan pada hasil yan diperoleh pada penelitian ini, dapat disimpulkan bahwa: (1) Atribusi kekerasan isteri korban KDRT dibedakan menjadi faktor internal dan faktor eksternal. Adapun dimensi atribusi kekerasan isteri adalah lokasi penyebab terjadinya kekerasan, stabilitas danaya kekerasan, dan pengendalian diri terhadap kekerasan. (2) Strategicoping yang dipergunakan isteri dalam menghadapi kekerasan suami bisa dibedakan menjadi dua yaituProblemFocused coping (PFC) danEmotional Focused Coping (EFC). (3) Strategi PFC dipilih ini karena dipengaruhi oleh: faktor internal individu yaitu karakteristik pada kelima individu informan yang cenderung bersabar dan bertahan ketika mendapatkan tekanan, serta faktor eksternal individu yaitukemampuan dan pengalaman yang dilakukan, dan kemampuan secara finansial. Adapun strategi EFC dipilih karena adanya faktorinternal dari diri yang mempunyai karakter sabar, pasrah, dan menyerah sebelum permasalahan terjadi lebih lanjut, serta faktor eksternal yaitu keluarga yang memang terkesan pasif atas permasalahan yang dihadapi oleh korban.

\section{DAFTAR RUJUKAN}

Laporan Kasus KPPA Kabupaten Ponorogo tahun 2013 s.d. 2017.

Nurhayati, Siti Rohmah. Peningkatan Kemampuan Menggunakan Problem Focused Coping Perempuan Korban Kekerasan dalam Rumah Tangga. Humanitas: Indonesian Psychological Journal. Vol. 3 No. 1, Januari 2006. 
Mclean, J.A., Strongman, K.T. Psycological Distress, Causal Attributions, and Coping. New Zealand Joumal Of Psicology. Vol. 36, No. 2. Juli 2007.

Hakimi, M. (Ed), Membisu Demi Harmoni "Kekerasan Terhadap Istri dan Kesehatan Perempuan di Jawa Tengah, Indonesia", LPKGM-FK-UGM yogyakarta, Rifka Annisa WCC Yogyakarta, Umea UniversitySweden, Women's Health Exchange USA: 2001. 